\title{
Dividend cession - Investigating the South African tax implications
}

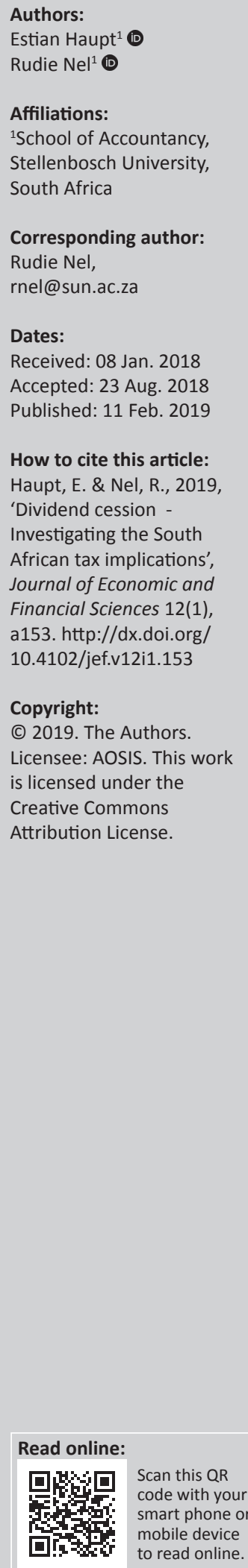

\section{Orientation: The South African tax legislation in respect of dividend cession.}

Research purpose: The objective of this article was to investigate the tax implications of a dividend cession for the cedent, cessionary and declaring company involved in the cession in order to provide guidance regarding the tax implications arising from such cession.

Motivation for the study: The introduction of specific anti-avoidance provisions and amendments to tax legislation complicated the tax treatment of a dividend cession. Current literature and guidance contains a brief reference to the capital gains tax implications, while other guides deal exclusively with the dividends tax implications. Based on the lack of definitive guidance of other taxes resulting from a dividend cession, this investigation is considered necessary.

Research approach/design and method: This study involved an interpretative analysis of the tax legislation and incorporates other literature on the research objective to describe the tax implications as a result of dividend cession. The mode of inquiry for this study is qualitative in nature and follows a doctrinal research method.

Main findings: Findings suggest that although the classification of a dividend cession could be a usufruct (a real right), the practical tax implications with reference to dividends could not have been the intention. The submission is therefore that the tax implications should be as a personal right. Furthermore, the introduction of specific anti-avoidance provisions resulted in an instance of possible double taxation which was noted, which is submitted as a possible unintended consequence as a result of legislation amendments.

Practical/managerial implications: The practical value of the article lies in the guidance in respect of the tax implications which taxpayers could consider in transactions pertaining to dividend cession.

Contribution/value-add: Instance of double taxation documented and submitted as possible unintended consequence which could inform further debate on the topic.

\section{Introduction}

With effect from 01 April 2012, dividends tax was introduced in South African tax law because of a need to shift from a company-level tax to an internationally applied method of shareholderlevel tax (South African Revenue Service [SARS] 2008:24), with exemptions depending on the nature of the beneficial owner. To provide for the taxation of a dividend cession and prevent potential abuse of the exemptions, various provisions have been inserted and amended in the Securities Transfer Tax Act No. 25 of 2007 (South Africa 2007) (the STT Act) and the Income Tax Act No. 58 of 1962 (South Africa 1962) (the IT Act). To assist taxpayers in the interpretation and application of the tax laws, the SARS drafts and issues several guides, including the Comprehensive Capital Gains Tax Guide (Issue 5), the Tax Guide for Share Owners (Issue 4) and the Comprehensive Guide to Dividends Tax. The Comprehensive Capital Gains Tax Guide (SARS 2015a:314, 315) contains a brief reference to the capital gains tax implications of a cession of a dividend, while the Comprehensive Guide to Dividends tax (SARS, 2015b) deals exclusively with the dividends tax implications of a dividend cession. No further guidance is provided in respect of the effect of a dividend cession in relation to normal tax (including capital gains tax) and its interaction with dividends tax, securities transfer tax and donations tax. Based on the lack of definitive guidance of other taxes resulting from a dividend cession, this investigation is considered necessary.

In a generic dividend cession transaction, there are three parties involved: the person, who was the beneficial owner of the dividend, who cedes such right (the cedent); the person who receives 
the right to the dividend as a result of the cession and becomes the beneficial owner (the cessionary); and the declaring company in which the shares are held which subsequently pays the underlying ceded dividend. As introduction to the investigation of the tax implications of a dividend cession, the meaning of 'dividend', 'share', 'beneficial owner', 'cession' and whether the right to receive a dividend is capable of being validly ceded requires discussion. Section 64D, read with section 1, of the IT Act defines a 'dividend' for purposes of dividends tax which includes any amount transferred or applied by a resident company, for the benefit or on behalf of any person, in respect of any share in that company. A 'share' is defined in the IT Act as any unit into which the proprietary interest in a company is divided. The meaning of a 'share' has also been considered in Standard Bank of South Africa Ltd and Another v Ocean Commodities Inc and Others (1983:151) where Corbett JA described a share as a bundle or conglomerate of personal rights which entitles the holder thereof to an interest in the company, its assets and dividends. Dividends tax is a tax on the beneficial owner. The 'beneficial owner' of a share, for purposes of dividends tax, is defined as the person who is entitled to receive the benefit of the dividend attaching to a share (section $64 \mathrm{D}$ of the IT Act). Applying the definition to Standard Bank of South Africa Ltd and Another $v$ Ocean Commodities Inc and Others (1983), the beneficial owner will be the person who has a right entitling that person to an interest in the dividends of the company.

A 'cession' is not defined in the IT Act and must therefore be given its grammatical and ordinary meaning which was determined by the court in Lynn \& Main Inc v Brits Community Sandworks CC (2008) as a method by which incorporeal rights are transferred between a transferor (the cedent) and a transferee (the cessionary) by means of a mere agreement. An existing right, even when subject to conditions, can effectively be ceded while the cession of a spes or mere hope is more controversial (Van der Merwe 1998:355). The controversy stems from the fact that a future right is a nonexistent right which cannot be transferred under common law; however, in Lynn $\mathcal{E}$ Main Inc $v$ Brits Community Sandworks CC (2008), it was held that a conditional right and a mere spes can be validly ceded (Van der Merwe 1998). The right to receive a dividend (whether declared or not) can thus be validly ceded and the classification of the nature of such right ceded (as a personal right or a real right) merits further investigation as the tax implications based on this classification will differ. This article investigates the tax implications of a dividend cession which will result in a change of the beneficial ownership. The value-added tax (VAT) consequences have already been investigated by Haupt and Nel (2017) and therefore are excluded as a tax consequence investigated in this article.

\section{Research objective, research method and value of the research}

The objective of this article is to investigate the tax implications of a dividend cession for the cedent, cessionary and declaring company involved in the cession, in order to provide guidance regarding the tax implications arising from such cession. This study involves an interpretative analysis of the tax legislation and incorporates other literature on the research objective to describe the tax implications as a result of dividend cession. The mode of inquiry for this study is qualitative in nature and follows a doctrinal method as described by Hutchinson and Duncan (2012:101). In terms of this method, the specific requirements of the Act were firstly identified and the issues regarding interpretation from a legislative perspective analysed. This was followed by the identification of sources of which the primary sources were accepted as case law, interpretations and guides from SARS, articles, dissertations and academic books. The sources were consulted to obtain an understanding of the interpretation of current provisions of the Act in the absence of guidance specifically pertaining to dividend cessions. Based on the sources, the relevant issues were synthesised in order to enable a conclusion on the tax implications of a dividend cession. Doctrinal research is submitted as relevant in any field of enquiry, such as law and accounting, where doctrines (principles and rules) are developed through a process of consensus (Coetsee \& Buys 2018:74). In the field of tax legislation, which is subject to annual amendments, comments of academics and practitioners could inform debate regarding amendments if uncertainty or bias is highlighted in tax legislation. The general aim of doctrinal research is to persuade other legal professionals (fellow legal academics, practising lawyers, judges and law reformers) of the researcher's understanding of the state of the law and the seriousness of any deficiencies identified with possible external social effects (Roux 2014:178). Investigating the tax implications could therefore enable the identification of any uncertainty or unintended consequences, such as double taxation, which could be regarded as deficiencies in the tax legislation and could serve as basis for future research.

Doctrinal legal research needs to be systematic, purposive and have a robust framework (McKerchar 2008:19). The article followed a systematic approach by adhering to the doctrinal method described by Hutchinson and Duncan (2012), which has also been applied in previous legal doctrinal studies relating to tax implications of transactions. In order to investigate the tax consequences, the following steps were performed:

- investigating the nature of the rights attaching to a share and the nature of the rights created as a result of a dividend cession

- investigating the tax implications of a dividend cession for the cedent, cessionary and declaring company involved in the cession.

The value of the article lies in the guidance it could provide regarding the tax implications of a dividend cession, as there is currently a lack of definitive guidance on the topic. 


\section{Rights associated with a share and the right to receive a dividend}

The tax implications of a dividend cession, which forms part of the bundle of rights that constitutes a share, may differ depending on the nature thereof as a real right or a personal right. The Comprehensive Guide to Capital Gains Tax provides a share as an example of an incorporeal object which cannot be seen, heard, touched smelled or tasted (SARS 2015a:42). A share entitles a shareholder to different rights (the right of ownership in the company, the right to vote and the right to participate in distributions). From a tax perspective, a consideration for the presence of a usufruct in respect of an asset is due as it represents a separate right with separate tax implications.

De Koker and Williams (2016b:23.6) state that a usufructuary interest is a real right that entails the enjoyment of the income from the property of another, which could consist of the dividends on shares. The right to receive a dividend, where that right constitutes a usufruct, could thus constitute a real right being ceded. In Cooper v Boyes NO and Another (1994), consideration was given to whether a share can be subject to a quasi-usufruct and it was held that it would only apply when a share is bequeathed, or intentionally made subject to a usufruct and the usufructuary will have the right to receive dividends or other benefits. Leos (2006:126-146) argued that a share, for example a preference share, could be subject to a quasi-usufruct having regard to the rights and privileges attaching to that share. South African Revenue Service (2015a:314) also stated that the sale of a future dividend is a quasi-usufruct.

In contrast to the argument that a share could be subject to a usufruct (a real right), the judgement in Standard Bank of South Africa Ltd and Another v Ocean Commodities Inc and Others (1983:151) described a share as a complex bundle of personal rights. In agreement herewith, De Koker and Williams (2016b:23.6) also state that a contractual right to receive the net income of shares will not be similar to a usufruct of shares as it is a personal right. Because of the contradicting views on whether a share represents a real right (usufruct) or a personal right, further investigation is deemed necessary as the tax implications would differ based on this classification. To distinguish between a real right and a personal right, several theories have been developed which are discussed in Silberberg and Schoeman's Law of Property (Badenhorst, Pienaar \& Mostert 2015:4.3) which will be briefly discussed and applied below.

The classical theory has regard to the relationship to which the right relates. The relationship could be between a person and an object or between persons (Badenhorst et al. 2015:4.3). A real right is concerned with the relationship between a person and an object, which provides the owner thereof with full rights of control over that object (Van der Walt \& Maass 2012:40). Further to real rights, limited real rights have been recognised which are concerned with the relationship of a person and the object of another, which confers on the owner of the right, a right over the property of another (Johnson 2016:75). A personal right is concerned with the relationship between two persons, where the owner of the right merely has a right to enforce performance by another person (Badenhorst et al. 2015:4.3.1).

In terms of the personalist theory, a real right and a personal right are distinguished by having regard to whether the right is enforceable against all persons or whether the right is enforceable only against a particular person who is a party to that obligation (Van der Merwe 2015:40,60). A real right can be enforced against any person who deals with the object to which that right relates in a manner which violates or encroaches on that right (Badenhorst et al. 2015:4.3.2) and can therefore be described as an absolute right (Van der Walt \& Maass 2012:39). A personal right, however, is a right that is enforceable only against a particular person or group of persons on the basis of a legal relationship between them, for example, the parties to a contract. Personal rights can therefore be described as relative rights (Badenhorst et al. 2015:4.3.2).

When confronted with the distinction between a real right and a personal right, our courts have further had regard to the subtraction from the dominium test (Badenhorst et al. 2015:4.4; Ex Parte Geldenhuys 1926:164). The subtraction from the dominium test is concerned with whether the right diminishes the ownership of the owner of the object by restricting the owner from exercising all the rights of ownership (Van der Walt \& Maass 2012:40). A real right places a burden on the owner's right of ownership of an object, while a personal right places the burden of performance on the owner of an object in his personal capacity (Badenhorst et al. 2015:4.3.6). The subtraction from dominium test further provides that a limited real right exists where the right burdens or diminishes the owner's rights to such an extent that it can be said that part of the ownership of the object has been transferred to the other person (Van der Walt \& Maass 2012:39).

The intention test has also been applied which focuses on whether the parties intended the particular right to be binding on any successors in title (Van der Walt \& Maass 2012:44; Cape Explosive Works Ltd and Another v Denel (Pty) Ltd and Others 2001:21). An intention to bind successors in title of the object indicates a real right, while no such intention indicates a personal right (Badenhorst et al. 2015:4.3.6-4.3.7).

In determining whether a real right or a personal right exists, it is therefore important to establish the object over which that right exists and the relationship between the parties be identified. The following different rights will be considered:

- firstly, the nature of the bundle of rights constituting a share, which confers rights between the shareholder and the company

- secondly, the right which comes into existence between the shareholder (as cedent) and the cessionary as a result of the cession. 


\section{Rights attaching to a share}

The relationship between a shareholder and a company is regulated by the Companies Act No. 71 of 2008 (South Africa 2008) (the Companies Act). Section 1 of the Companies Act defines a 'shareholder' to mean the holder of a share who is entered as such in the securities register of that company. Section 37(9) of the Companies Act further provides that a person acquires the rights associated with any particular securities when that person's name is entered in the company's certificated securities register or as determined by the rules of the central securities depository. Consequently, a person registered as the owner of a security acquires rights against the company as the registered shareholder.

A share, as a complex bundle of rights, entitles the registered shareholder to receive notices, to vote in respect of these shares, to receive dividends and/or a return of capital (Joubert 2012:193). The shareholder therefore holds the direct ownership of the share, in other words the relationship is between a shareholder and an incorporeal object, which can be enforced against all other persons. The right that a shareholder has against a company, which constitutes a share, could accordingly be regarded as a real right over an incorporeal object. The right which exists between a cedent (the shareholder) and the cessionary as a result of a cession should then be considered.

\section{Rights created as a result of a dividend cession}

The Companies Act makes provision for a situation where a person, other than the registered shareholder, could hold a 'beneficial interest' in a share. A 'beneficial interest' is defined in section 1 of the Companies Act and includes a person who has a right to receive a distribution. The declaring company would, however, only be concerned with the registered shareholder and not any other person (Standard Bank of South Africa Ltd and Another v Ocean Commodities Inc and Others 1983:289) and only the registered shareholder can enforce the rights attaching to the shares (Joubert 2012:193). Where a person acts as a nominee of the beneficial owner, he would likely bind himself to act on behalf of the beneficial owner in terms of an agreement with the beneficial owner (Joubert 2012:193). The relationship between the parties would therefore be determined by way of agreement.

Applying the classical theory and personalist theory, the right which a cessionary has against a cedent would be classified as a personal right, because the object of the right to receive a dividend would be the performance of the cedent and the cessionary will be able to oblige only the shareholder to act, or not act, in a certain manner. In terms of the subtraction from the dominium test, it is contemplated that the right of the cessionary would diminish the cedent's ownership of the shares by limiting the ownership to such an extent that it could be said that ownership of part of the object (the right to the enjoyment of any dividends) has passed to the cessionary. This test therefore indicates that the right to receive a dividend would constitute a real right.
With the application of the intention test, it is contemplated that the intention of the parties would depend on the wording of their agreement. The outcome of this test would therefore be dependent on the facts and circumstances of each case. Based on the theories and tests, the classification of a right to receive a dividend as a result of a cession is presented in Table 1.

Accordingly, the nature of the right between the cessionary and cedent would depend on the circumstances of each case although it is submitted as a personal right in principle. Concluding on whether the right constitutes a personal right or a real right is especially relevant when determining whether the rights created as a result of a dividend cession could constitute a usufruct. Findings suggest that a share can be subject to a usufruct or arguably even a quasi-usufruct if there is a clear intention to create a usufruct.

In the absence of a clear intention to create a usufruct by means of a dividend cession, the rights attached to a share are submitted, in principle, as a complex bundle of personal rights. The following tax implications are therefore discussed for both a real right and a personal right:

- securities transfer tax

- donations tax

- normal tax implications of a dividend cession

- normal tax and dividends tax implications of the receipt of a dividend ceded.

\section{Securities transfer tax}

The STT Act was introduced in 2007 and it provides for a tax known as the securities transfer tax ('STT'). An amendment, effective from 01 April 2012, to the definition of 'security' in section 1 of the STT Act, is of key importance in respect of the STT liability as a result of a dividend cession. The STT implications of a dividend cession prior to and on/or after 01 April 2012 are therefore investigated.

Section 2 of the STT Act provides that STT will be levied where there is a 'transfer' of a 'security' issued by a close corporation or company incorporated in the Republic of South Africa. In respect of a cession prior to 01 April 2012, section 1 of the STT Act defined a 'security' to specifically include any right or entitlement to receive any distribution from a company or close corporation. South African Revenue Service (2007:5) expressly stated that the cession of dividend rights would therefore be subject to the provisions of the STT Act. A further requirement of section 2 of the STT Act is that there must be a 'transfer' of a security. Section 1 of the STT Act defines a transfer broadly and includes a cession or disposal in any manner. Specifically excluded from the

TABLE 1: Classification of the cession of a dividend as a real right or a personal right.

\begin{tabular}{ll}
\hline Theory & Classification of cession of dividend \\
\hline Classical theory & Personal right \\
Personalist theory & Personal right \\
Subtraction from the dominium test & Real right \\
Intention test & Dependent on wording of agreement \\
\hline
\end{tabular}


definition is any transfer which does not result in the change of beneficial ownership and for purposes of this study, a dividend cession would have resulted in a change of beneficial ownership and constitute a transfer. Prior to 01 April 2012, a dividend cession would have constituted the transfer of a security and result in a liability for STT. Section 7(2) of the STT Act determines that any participant, member or company that was held liable to pay the STT may recover such amount from the person to whom that security was transferred. The result is therefore that the person who receives the transfer (the cessionary) will be accountable to either pay or refund the STT.

In respect of a cession on or after 01 April 2012, the definition of 'security' in the STT Act was amended to remove any right or entitlement to receive any distribution from a company or close corporation (TLAA No. 24 of 2011). South African Revenue Service (2011:172) explained that a cession of a dividend would no longer be subject to STT, as a receipt of a dividend acquired by way of a cession is viewed as an income stream which is independent from the underlying share and as such will be treated as ordinary revenue. The right to receive a dividend will, on or after 01 April 2012, not be a 'security' for STT purposes and no STT liability will arise upon cession thereof.

\section{Donations tax}

A 'donation' is defined in section 55 of the IT Act to mean a gratuitous disposal of property. The Oxford Dictionaries (Oxforddictionaries.com 2016) define 'gratuitous' as something 'done without good reason', 'uncalled for' or 'given free of charge'. The test to determine if a disposition amounts to a donation under common law was confirmed by Marais JA in Welch $v$ CSARS (2004:22) as whether the disposition was motivated by 'pure liberality' or 'disinterested benevolence'. In determining whether a disposition is gratuitous, regard would be given to the ordinary meaning of the word as well as the common law test. In a rational transaction, the cessionary would have to pay consideration in exchange for the right received from the cedent and no gratuitous disposal would take place. Even where a disposition is not gratuitous, however, donations tax could still be levied in terms of section 58 of the IT Act, if the Commissioner of SARS is of the opinion that the consideration received for the disposal does not reflect adequate consideration. The Tax Court in ITC 1599 (1995:98) submitted a comparison between the fair market value of the asset disposed of and the fair market value of the consideration received to determine adequate consideration. The term adequate consideration would not necessarily mean 'fair market value' and commercial considerations could justify transactions which are concluded at less than market value (De Koker \& Williams 2016b:23.5), although the 'fair market value' would be the starting point of such a determination.

In the calculation of donations tax in respect of the disposal of a personal right, the value will be the 'fair market value', as contemplated in section $62(1)(\mathrm{d})$ of the IT Act. Section 55 of the IT Act determines that the 'fair market value' will be the price which could have been obtained between a willing buyer and willing seller dealing at arm's length in the open market. Determining fair market value could be challenging as the value of the share could include, but not be equal to the value of the right to receive a dividend. The value of the share would therefore not necessarily be an indication of the value of the right to receive a dividend. Parties could have regard to the dividend history of the applicable share, the current economic circumstances and the financial position and forecasts of the relevant company, in order to determine the price that they are willing to pay for potential future dividends. Such a determination would have to factor in the risk of no dividends being declared which would further complicate the calculation of the cession for a limited time as well.

While the right constitutes a real right that provides a person with the right of enjoyment of income over the shares of another, the right will constitute a usufruct or other like interest (De Koker \& Williams 2016b:23.6). Section 62 of the IT Act deems the value of a usufruct or similar interest in property to be an amount capitalising at $12 \%$ the annual value of the right of enjoyment over which the interest is held, over the expectation of life of the donor or, if the right is to be held for a shorter period, over that period.

While a shareholder cedes the right to receive a dividend to a cessionary for no consideration, or for a consideration which is not adequate in the opinion of the Commissioner of SARS, the cedent would be donating, or be deemed to donate, an asset to the cessionary and donations tax will be applicable. Section 59 of the IT Act places the liability for donations tax on the donor (cedent), provided that the liability shall be jointly and severally on the donor and donee (cessionary) where the donor fails to pay the donations tax within the prescribed period. When income producing assets are donated, section 7 of the IT Act must be considered. As an anti-avoidance measure, this section provides for circumstances when income will be deemed to have been accrued or to have been received by a person, notwithstanding that the asset producing such income has been donated to a different person.

\section{Normal tax implications of a dividend cession}

A share is a complex bundle of rights, one of which entitles the registered shareholder to receive dividends. When the right to receive a dividend is ceded, a part of the share is disposed of in exchange for consideration. To determine whether the amount received by the cedent will be capital or revenue in nature, the intention of the taxpayer with the share, as an asset of which a part is disposed of, must be determined for the purpose of calculating 'gross income'. The amount could be revenue in nature (for instance where 
the cedent acquired the share with the intention of disposing of a part thereof in a scheme of profit making) or capital in nature (for instance where the taxpayer acquired and held the share as a capital asset and realised a fortuitous gain upon its disposal). Specifically with regard to equity shares, the IT Act contains section 9C which deems the proceeds from the disposal of a 'qualifying share' to be of a capital nature in certain circumstances. A 'qualifying share' is defined in section 9C of the IT Act to mean an equity share which has been disposed of by a taxpayer who, immediately prior to such disposal, had been the owner of that share for a continuous period of at least 3 years. Where a cedent has held a share for more than 3 years and subsequently disposes of a part of that share, by way of a cession of the right to receive a dividend, the receipt or accrual will be of a capital nature. Furthermore, it has been established that a dividend cession can constitute either a personal right or a real right (in the form of a usufruct). Accordingly, the normal tax implications of a dividend cession are subsequently investigated as follows:

- the position of the cedent considered from the perspective if the receipt is revenue in nature or capital in nature (with the necessary distinction between a real right and a personal right)

- the position of the cessionary considered from the perspective if the expenditure incurred is revenue in nature or capital in nature (with the necessary distinction between a real right and a personal right).

\section{Position of the cedent}

\section{Receipt revenue in nature}

Where the cedent receives an amount that is revenue in nature, that amount will be included in 'gross income' and enable consideration of exemptions which could result in no normal tax being payable. The exemptions to be considered are contained in section $10(1)(\mathrm{k})$ of the IT Act, which applies to the receipt of a dividend, and section $10 \mathrm{~B}$ of the IT Act which applies to a foreign dividend. Accordingly, on the basis that the receipt of a dividend or foreign dividend could qualify for an exemption, it must be determined if the receipt will constitute a 'dividend' or 'foreign dividend'.

A 'dividend' is defined in section 1 of the IT Act and refers to an amount transferred or applied by a company for the benefit of any person in respect of any share in that company. A 'foreign dividend' is defined in section 1 of the IT Act and would include an amount applied by a company which is not a resident of South Africa. In the case of a 'dividend' cession, the amount received by the cedent is received from the cessionary as consideration for the disposal and is not transferred or applied by a company in respect of any share in that company or foreign company. The dividend exemptions will therefore not apply and the amount received by the cedent will constitute income.

The cedent could also incur expenditure in the production of the income from the dividend cession in respect of which a tax deduction should be considered. Section 11(a) of the IT Act provides that an amount of expenditure that is actually incurred in the production of income could qualify as a deduction, provided that such expenditure is not of a capital nature. Where a person incurs expenditure in the production of an amount which is exempt from normal tax, for example the acquisition of a share that will produce exempt dividends, the expenditure will not qualify as a deduction. A cedent could acquire the share, which includes the right to receive dividends, with the intention of earning taxable income by ceding the right to receive a dividend. In such a case, a deduction could be applicable for the expenditure actually incurred in the production of income. The expenditure actually incurred to acquire the share will have been incurred to acquire the entire bundle of rights that constitute the share, which would therefore include a portion which is expended to acquire the right to receive a dividend. The Supreme Court of Appeal in CSARS v Mobile Telephone Networks Holdings (Pty) Ltd (2014:12) confirmed that expenditure laid out for a mixed purpose may be apportioned. Where a share is acquired with the intention of utilising a portion of that share in the production of income, an apportionment of the expenditure actually incurred could be made. A portion of the expenditure actually incurred by a taxpayer to acquire a share could, in such circumstances, be deductible.

\section{Receipt capital in nature}

Where the cedent receives an amount that is capital in nature, that amount will not be included in 'gross income' but rather considered in terms of the Eighth Schedule to the IT Act (the Schedule) for possible capital gains tax implications. As provided for in paragraph 3 of the Schedule, a person's capital gain, upon the disposal of an asset, is the amount by which the proceeds exceed the base cost of that asset. For a capital gain, or capital loss, to arise, there must be an 'asset' and a 'disposal' each of which is subsequently considered. The investigation starts with the implications for a personal right and closes with the implications of a real right.

The term 'asset' is broadly defined in paragraph 1 of the Schedule and includes property of whatever kind, irrespective of whether that property is movable or immovable, corporeal or incorporeal. The Comprehensive Guide to Capital Gains Tax contains a list of examples of assets that specifically includes shares (SARS 2015a:39). The definition of 'asset' in paragraph 1 of the Schedule further provides that any right or interest, of whatever nature, in any property that qualifies as an asset will also constitute an asset. It follows that the right to receive a dividend, being a right or interest in a share, will qualify as an asset for purposes of the Schedule. The right to receive a dividend can, however, be equated with the right to claim payment from the company, if a dividend is declared. The Comprehensive Guide to Capital Gains Tax (SARS 2015a:45) states that the right to claim payment, as a personal right, would not always be an asset for capital gains tax purposes. This statement is in line with the reasoning of Cassidy, as expressed by Swart (2005:2), that personal rights, 
which are not capable of transmission or valuation, do not constitute assets for capital gains tax purposes. With the creation of personal rights, the common thread of events which would qualify as assets is that the creation must result in a loss, limitation, restriction or diminution of the disposer's rights (Swart 2005:8). Where the right to receive a dividend is ceded in terms of a contract, it is submitted that a personal right will be created in terms of which the cessionary can oblige the cedent to perform by paying any dividend. The personal right will result in a limitation or diminution of the cedent's rights attaching to the share and will therefore constitute an asset for capital gains tax purposes.

The definition of 'disposal' in paragraph 1 of the Schedule refers to paragraph 11 of the Schedule. Of particular interest is paragraph 11(1)(a) of the Schedule which provides that any cession of ownership of an asset will be a disposal. Accordingly, where the right to receive a dividend (the asset) is ceded (the disposal), a capital gains tax event will occur. What remains to be determined is the proceeds and the base cost of the asset that is being disposed of. The proceeds in respect of the disposal of an asset is governed by paragraph 35 of the Schedule which stipulates that proceeds is the amount received by or accrued to a person in respect of a disposal. Where the right is disposed of by means of a donation, or between connected persons, the proceeds will be deemed, by paragraph 38(1) of the Schedule, to be the market value of the asset. Paragraph 31(1)(g) provides that the market value will be equal to the amount that could have been obtained between a willing buyer and willing seller who are dealing at an arm's length in the open market. Such a determination could be challenging as the parties will likely have to take into account not only the share price, but also dividend history of the share, current economic circumstances as well as the financial position and forecasts of the relevant company. The base cost of an asset, in terms of paragraph 20 of the Schedule, will be the cost incurred to acquire the asset. The cedent purchases a share at a cost incurred to purchase all the rights attaching to that share. The right to receive a dividend from that share could form part of the initial cost of the share which must be determined separately. The provisions of paragraph 33 of the Schedule, containing the method for determining the base cost of the part disposed of in a part-disposal, must be applied. The base cost attributable to the part disposed of must be calculated as the market value of the part disposed of, divided by the market value of the entire asset (the share) and multiplied by the base cost of the entire asset. The cedent will have to determine that market value of the share as well as the market value of the right to receive a dividend, after which it can determine the capital gains tax implication of the cession.

The right to receive a dividend could also be regarded as a real right if the intention was to create a usufruct. In accordance herewith, the Comprehensive Guide to Capital Gains Tax states that the sale of a future dividend stream is a quasi-usufruct (SARS 2015a:314). As with a personal right, the capital gain would be the amount by which the proceeds exceed the base cost. The determination of the proceeds and base cost will be the same as with a personal right with the exception of the calculation of the market value of the part being disposed of. Paragraph 31(1)(d) specifically provides a method for calculating the market value of a usufructuary or similar interest in an asset as an amount determined by capitalising, at $12 \%$, the market value of the full ownership of the asset over the expected life of the person who acquires that right, or if the right is to be held for a lesser period, over that period. Paragraph 31(2)(a) of the Schedule provides that the rate of $12 \%$ could be adjusted if the Commissioner of SARS is satisfied that the property could not reasonably be expected to produce an annual yield of $12 \%$.

\section{Position of the cessionary}

\section{Expenditure incurred revenue in nature}

Where a cessionary acquires the right to receive a dividend for purposes of earning exempt dividends (exempt from normal tax as a result of section 10(1)(k) of the IT Act), any expenditure incurred will not be tax deductible, as section 23(f) of the IT Act specifically provides that no deduction will be allowed for expenses incurred in respect of amounts received that do not constitute income as defined in section 1 of the IT Act. Should an instance occur where the receipt of the dividend is not exempt from normal tax, subject to section 11(a) of the IT Act, a deduction is conceivable. Similarly, should the cessionary acquire the right to receive a dividend with the intention of disposing thereof (thereby becoming the cedent) in a scheme of profit making, the expenditure actually incurred could be tax deductible in terms of section 11(a) of the IT Act.

The cedent could also provide the right to receive a dividend as consideration for the purchase of an asset from the cessionary. In CIR v Cactus Investments (Pty) Ltd (1996:187), it was held that if the cessionary receives a dividend cession as consideration for trading stock, the amounts would stand for inclusion in income. The cessionary would, in such a case, not merely receive the dividend as a result of shareholding but rather because of providing such trading stock in a barter transaction. The focus on counter performance in determining the taxability of receipts was also again emphasised in the case CSARS v Brummeria Renaissance (Pty) $L t d$ (2007). Consequently, the value of the right to receive the dividend could be subject to normal tax, if the cessionary did not merely receive the dividend ceded in capacity as a shareholder but provided other counter performance.

\section{Expenditure incurred capital in nature}

A cessionary could acquire the right to receive a dividend as a capital asset, for long-term investment purposes, and expenditure incurred would constitute the base cost of such an asset. By implication, this scenario is only conceivable where the cessionary acquired the right to a dividend for a period over which multiple dividends would be received (recurring) and not only for one dividend declaration. Upon expiry of that period, a disposal will take place, 
as contemplated in paragraph $11(1)(b)$ of the Schedule at which time the right would have no value and the proceeds for the expiry would be zero, resulting in a capital loss for the cessionary. Where the right to receive a dividend is used solely to produce dividends that are exempt from normal income, such capital loss will be disregarded in terms of paragraph 64 of the Schedule. Where the right to receive a dividend constitutes a usufruct, paragraph 15(c) of the Schedule would apply and any capital loss realised must be disregarded in determining the capital gain or loss of the cessionary.

\section{Normal tax and dividends tax on subsequent receipt of the dividend}

The normal tax and dividends tax implications for the cedent and cessionary with the subsequent receipt of the dividend remain to be investigated. The right to receive a future dividend is an existing right and can be validly ceded (ITC 1378 1983:234). The right to receive a dividend could also be a mere hope or spes, which is not an existing right, and still validly be ceded (Lynn \& Main Inc v Brits Community Sandworks CC 2008, in Van der Merwe 1998:362). Accordingly a dividend cession can validly occur prior to the declaration of the dividend. The timing of the cession is submitted of key importance to establish the 'beneficial owner' for dividends tax purposes as well as the inclusion in gross income. In respect of the accrual principle, the 'last date to register' or record date in respect of the dividend declared would be decisive in establishing the beneficial owner to whom a dividend accrues. A dividend could therefore be ceded after declaration but before the record date of such dividend (being the accrual date). A cession subsequent to dividend declaration could thus be prior to accrual date in instances where the record date is after the declaration date. The timing of the dividends cession is discussed subsequently.

\section{Cession prior to dividend declaration}

Dividends tax is a tax on the 'beneficial owner' with the obligation on the company to withhold $15 \%$ of the amount of any dividend, unless the 'beneficial owner' is an entity that is exempt in terms of section $64 \mathrm{~F}$ of the IT Act. A dividend cession that occurred prior to dividend declaration will result in the cessionary being regarded as the 'beneficial owner' and liable for dividends tax (unless an exemption in terms of section $64 \mathrm{~F}$ of the IT Act applies).

Where a dividend is paid by a company, the company need only be concerned with the registered shareholder (Standard Bank of South Africa Ltd and Another v Ocean Commodities Inc and Others (1983:289)) and will therefore pay such amount to the registered shareholder. Confusion may arise where a valid cession took place and subsequently the dividend is physically received by the cedent (Croome et al. 2013:79). In order to determine whether the cedent will be subject to normal tax on an amount it receives, it must be determined if that amount must be included in 'gross income' as defined in section 1 of the IT Act. The definition of 'gross income' includes any amount that is received by a resident, on the condition that it is received for his own benefit and on his own behalf (Geldenhuys v CIR 1947:431). Where a cedent, as a registered shareholder, receives a dividend on behalf of the cessionary, as a 'beneficial owner', the cedent does not receive that amount for his own benefit and on his own behalf and that amount will not be included in 'gross income' or subject to normal tax (De Koker \& Williams 2016a:9.2). The amount will be included in the 'gross income' of the cessionary, irrespective of whether or not the amount is physically received by the cedent as a registered shareholder. The cessionary would then stand for consideration of exemptions in terms of section 10(1)(k) of the IT Act. Section 10(1)(k)(i)(ee) of the IT Act contains a specific anti-avoidance provision in terms of which a dividend will not qualify for the dividend exemption if received by or accrued to a company in consequence of any dividend cession. South African Revenue Service (2012:60) indicated that this anti-avoidance measure was inserted as the cessionary is merely purchasing an income stream with no meaningful stake in the underlying share. The effect of section 10(1)(k)(i)(ee) of the IT Act is that a dividend received by a company, as a result of a cession, would not be exempt from normal tax. In part, this antiavoidance could also be explained as the company in such an instance would not be liable for dividends tax because of the exemptions afforded in section 64F.

\section{Cession after dividend declaration}

In respect of a dividend cession that occurred after a dividend has been announced or declared, section 64EB of the IT Act is applicable. The cases contemplated would be those where the dividend is ceded and therefore has not been paid by the declaring company yet. This provision deems the cedent to be the 'beneficial owner' if the cessionary is an exempt entity as contemplated in section 64F. For example, where a resident company receives a dividend as a result of a cession that took place after the dividend was announced or declared, the deemed beneficial owner of that dividend will be the cedent and not the receiving company. The dividends tax liability will therefore be determined with reference to the entity type of the cedent and the tax liability, if any, will fall on the cedent. Where the cessionary is not an exempt entity, section 64EB will not apply and the beneficial owner of the dividend will be the cessionary, in which case the dividends tax liability will be on the cessionary. If the cession occurred after declaration and after the accrual date (record date), the declaring company would pay the dividend to the cedent as a registered shareholder. The cedent would therefore be regarded as the beneficial owner for dividends tax purposes as well as the person who stands to include an amount in gross income.

If the cession occurred after declaration but before the accrual date (record date), the declaring company would pay the dividend to the cessionary as a registered shareholder. The cessionary would therefore stand to include an amount in gross income and as a result of a cession after dividend declaration, the dividend would not be exempt if the 
cessionary is a resident company in terms of section 10(1)(k) (i) (ee)(A) of the IT Act. For dividends tax purposes, the cedent would be deemed to be the beneficial owner of the dividend if the cessionary is an exempt entity in terms of section 64EB notwithstanding the fact that the dividend accrued to the cessionary for gross income purposes. Based on the findings, it is conceivable that a situation could arise where the deemed beneficial ownership rules would apply and the cedent will be liable for dividends tax, while the cessionary could be a resident company who will receive a dividend that is not exempt from normal tax. The exemption from dividends tax afforded in terms of section $64 \mathrm{~F}(1)(\mathrm{l})$ of the IT Act only applies if the dividend was included in the income of 'that person' and would not apply as the cedent liable for the dividends tax did not include the dividend in income but rather the cessionary. The receipt of a dividend, as a result of the dividend cession, could be subject to tax in the hands of both the cedent (dividends tax) and the cessionary (normal tax).

\section{Conclusion}

The starting point for determining the tax implications of a dividend cession would be to determine the type of right being ceded (as a real right or a personal right). In principle, the different theories considered in the classification (Table 1) resulted in the possible classification of a dividend cession as a personal right or a real right. With regard to the tax consequences, it is not conceived that the intention of legislature could be to subject such a dividend cession to the tax consequences of a usufruct (real right). The tax implications of a usufruct (real right) would be determined by calculating the right of enjoyment of the property, usually over the life expectancy or period of enjoyment of the underlying property. This calculation for a dividend cession is not considered practical as an amount would be capitalised over the value of the shares, without any regard to the value of the right to a dividend which will be determined with reference to the financial position and standing of the declaring company. This argument rather posits that the tax consequences of a dividend cession would follow the consequences of a personal right and not a real right.

An investigation of the tax consequences suggests that the only tax consequences for the declaring company would be an STT liability in the case of unlisted shares prior to 01 April 2012, which is subject to a right to be refunded by the cessionary. The tax consequences for the cedent and the cessionary are presented in Table 2 .

With reference to the specific anti-avoidance provisions introduced, an instance of possible double taxation was noted. The deemed beneficial ownership rules could apply and the cedent will be liable for dividends tax in respect of the dividend. In addition, if the cessionary is a resident company, the section $10(1)(\mathrm{k})$ exemption would not apply resulting in the cessionary being liable for normal tax on the same dividend. Consequently, the receipt of a dividend, as a result of the dividend cession, could be subject to tax in the hands of both the cedent and the cessionary. In instances where the cessionary provided specific counter performance, goods or services, in exchange for the dividend ceded, an argument in favour of double taxation would be founded. In other instances where the cessionary only received the dividend ceded double taxation would, it is submitted, not arise. If it was not the intention for the anti-avoidance provisions to result in this double taxation, it should be clarified and amended accordingly. The exemption from dividends tax afforded in terms section $64 \mathrm{~F}(1)(1)$ of the IT Act

TABLE 2: Tax implications of a cession of the right to receive of a dividend.

\begin{tabular}{|c|c|c|}
\hline Variable & Cedent & Cessionary \\
\hline \multicolumn{3}{|c|}{ Taxes other than normal tax and dividends tax } \\
\hline Donations tax & $\begin{array}{l}\text { As a personal right, the value of a donation based on the market } \\
\text { value obtained between a willing buyer and willing seller dealing at } \\
\text { an arm's length. }\end{array}$ & - \\
\hline Securities transfer tax & - & $\begin{array}{l}\text { - Cession prior to } 01 \text { April 2012: Subject to STT. } \\
\text { - Cession on or after } 01 \text { April 2012: Not subject to STT. }\end{array}$ \\
\hline \multicolumn{3}{|c|}{ Normal tax on the cession of dividend } \\
\hline $\begin{array}{l}\text { Receipt or accrual of } \\
\text { revenue nature }\end{array}$ & $\begin{array}{l}\text { - Consideration received included in gross income and not exempt } \\
\text { from normal tax. } \\
\text { - A possible deduction of a portion of the acquisition expenditure } \\
\text { of the share. }\end{array}$ & $\begin{array}{l}\text { Consideration paid to cedent (expenditure incurred) to acquire the right to } \\
\text { receive a dividend will not be deductible, unless the right is on-sold or the } \\
\text { eventual receipt of the dividend is not exempt income. }\end{array}$ \\
\hline $\begin{array}{l}\text { Receipt or accrual of } \\
\text { capital nature }\end{array}$ & Part-disposal calculated on the market value. & $\begin{array}{l}\text { Expenditure incurred to acquire the personal right will constitute base cost } \\
\text { and upon expiry of such right, a capital loss will realise. }\end{array}$ \\
\hline \multicolumn{3}{|c|}{ Normal tax and dividends tax on subsequent receipt of the dividend: Cession prior to dividend declaration } \\
\hline Normal tax & None as dividend not received for own benefit. & $\begin{array}{l}\text { Dividend received for own benefit included in gross income and dividend not } \\
\text { exempt if the cessionary is a company and does not acquire the entire share. }\end{array}$ \\
\hline Dividends tax & None as deemed beneficial owner rules will not apply. & $\begin{array}{l}\text { The cessionary will be the beneficial owner and subject to dividends tax } \\
\text { unless the cessionary is exempt from dividends tax. }\end{array}$ \\
\hline \multicolumn{3}{|c|}{ Normal tax and dividends tax on subsequent receipt of the dividend: Cession after dividend declaration and after accrual date } \\
\hline Normal tax & $\begin{array}{l}\text { Dividend accrues to the cedent and will be included in gross income } \\
\text { and could be exempt. }\end{array}$ & $\begin{array}{l}\text { The dividend accrues to the cedent. The tax implications for the cessionary } \\
\text { will follow the normal rules relating to the receipt of an amount. }\end{array}$ \\
\hline Dividends tax & $\begin{array}{l}\text { The cedent will be the beneficial owner and subject to dividends tax } \\
\text { unless the cedent is exempt from dividends tax. }\end{array}$ & None as cedent subjected to dividends tax. \\
\hline \multicolumn{3}{|c|}{ Normal tax and dividends tax on subsequent receipt of the dividend: Cession after dividend declaration but prior to accrual date } \\
\hline Normal tax & None as dividend accrues to cessionary. & $\begin{array}{l}\text { Dividend accrued included in gross income and not exempt if the cessionary } \\
\text { is a company and does not acquire the entire share. }\end{array}$ \\
\hline Dividends tax & $\begin{array}{l}\text { Deemed beneficial owner rules apply and cedent subject to dividends } \\
\text { tax if not exempt. }\end{array}$ & None as cedent subjected to dividends tax. \\
\hline
\end{tabular}


not to subject a dividend to dividends tax if not exempt would not apply as the liability for dividends tax vests in the cedent and not the cessionary which included the dividend in income. This instance of double tax is conceived as an unintended consequence of the anti-avoidance provisions introduced of which the policy implication could require an amendment to eliminate the double taxation.

The findings of the study illustrate that as a result of the various amendments in respect of STT and income tax relating to the tax implications of dividend cessions, guidance is currently lacking. The recommendation is that the lack of definitive guidance on the tax implications of a dividend cession should be addressed in order to assist taxpayers in tax planning as well as their own tax calculations. In this regard, the type of right being ceded should be clarified as this classification would dictate the resulting tax consequences and findings suggest that the classification as a real right would not be practical based on the current tax implications in respect of valuation of such rights. Further guidance could serve as a deterrent for avoidance schemes as taxpayers would be well informed of the effects of any amendments made.

\section{Acknowledgements}

This article is based on the initial research conducted by the first author as part of his Master's degree in Taxation (Stellenbosch University), with the second author as the study leader for the said degree.

\section{Competing interests}

The authors declare that they have no financial or personal relationships that may have inappropriately influenced them in writing this article.

\section{Authors' contribution}

E.H. was responsible for the initial research conducted for the study while R.N. was the study leader. Both authors equally contributed to the writing of this article.

\section{References}

Badenhorst, P.J., Pienaar, J.M. \& Mostert, H., 2015, Silberberg and Schoeman's The Law of Property, 5th edn., viewed 28 February 2016, from http://www. mylexisnexis.co.za

Cape Explosive Works Ltd and Another v Denel (Pty) Ltd and others 20013 SA 569 (SCA). (19 March 2001).

CIR v Cactus Investments (Pty) Ltd [1996] 60 SATC 141. (17 April and 05 July 1996).

Coetsee, D. \& Buys, P., 2018, 'A doctrinal research perspective of master's degree students in accounting', South African Journal of Higher Education 32(1), 71-89.

Cooper v Boyes NO and Another 1994 (4) SA 521 (C). (25 August 1994).

Croome, B.J., Oguttu, A.W., Muller, E., Legwaila, T., Kolitz, M., Williams, R.C. et al., 2013, Tax Law: An introduction, 1st edn., viewed 08 July 2016, from https://books. google.co.za
CSARS v Brummeria Renaissance (Pty) Ltd 2007 (6) SA 601 (SCA), 69 SATC 205.

CSARS v Mobile Telephone Networks Holdings (Pty) Ltd [2014] ZASCA 4. (07 March 2014).

De Koker, A.P. \& Williams, R.C., 2016a, 'Chapter 9 "Dividends tax"', in Silke on South African Income Tax, viewed 17 June 2016, from http://www.mylexisnexis.co.za

De Koker, A.P. \& Williams, R.C., 2016b, 'Chapter 23 “Donations Tax, paragraph 23.5, Deemed Donations"', in Silke on South African Income Tax, viewed 17 June 2016, from http://www.mylexisnexis.co.za

Ex Parte Geldenhuys OPD 155. (15 April 1926 and 20 May 1926).

Geldenhuys v CIR 14 SATC 419 1947(3) SA 256 (C).

Haupt, E. \& Nel, R., 2017, 'Dividend cession and dividend distribution: The South African VAT implications', Journal of Economic and Financial Sciences 10(1), 13-25. https://doi.org/10.4102/jef.v10i1.2

Hutchinson, T. \& Duncan, N., 2012, 'Defining and describing what we do: Doctrinal legal research', Deakin Law Review 17(1), 83-119. https://doi.org/10.21153/ dlr2012vol17no1art70

ITC 1378 (1983) 45 SATC 230 (T). (11 April 1983).

ITC 1599 (1995) 58 SATC 88 (T). (31 July and 11 August 2995).

Johnson, E., 2016, 'Formulation of guidance on the South African income tax consequences of expenditure incurred in a tender process', Unpublished Master's thesis, Stellenbosch University, Stellenbosch.

Joubert, W.A., 2012, Law of South Africa. Companies: Part 1. Shares and share capital, the conceptual basis, viewed 17 April 2016, from http://www. mylexisnexis.co.za

Leos, E., 2006, 'Quasi-usufruct and shares: Some possible approaches', South African Law Journal 123(1), 126-146.

Lynn \& Main Inc v Brits Community Sandworks CC [2008] JOL 22418 (SCA). (17 September 2008).

McKerchar, M.A., 2008, 'Philosophical paradigms, inquiry strategies and knowledge claims: Applying the principles of research design and conduct to taxation', UNSW Law Research Paper No. 2009-31, eJournal of Tax Research 6(1), 5-22.

Oxforddictionaries.com, 2016, Oxford dictionaries language matters, viewed 16 June 2016, from http://www.oxforddictionaries.com/definition

Roux, T., 2014, 'Judging the quality of legal research: A qualified response to the demand for greater methodological rigour', Legal Education Review 24, 177-204. https://doi.org/10.2139/ssrn.2499258

SARS, 2007, Explanatory Memorandum on the Securities Transfer Tax Bill, 2007, South African Revenue Service, Pretoria.

SARS, 2008, Explanatory Memorandum on the Revenue Laws Amendment Bill, 2008 SARS, Pretoria.

SARS, 2011, Explanatory Memorandum on the Taxation Laws Amendment Bill, 2011, 27 January 2012, SARS, Pretoria.

SARS, 2012, Explanatory Memorandum on the Taxation Laws Amendment Bill, 2012 10 December 2012, SARS, Pretoria.

SARS, 2014, Tax guide for share owners (issue 4), 2014, 17 February 2014, SARS, Pretoria.

SARS, 2015a, Comprehensive guide to capital gains tax (issue 5), 2015, 09 December 2015, SARS, Pretoria.

SARS, 2015b, Comprehensive guide to dividends tax, 23 February 2015, SARS, Pretoria.

South Africa, 1962, Income Tax Act, No. 58 of 1962 (as amended), Government Printer, Pretoria.

South Africa, 2007, Securities Transfer Tax Act, No 25 of 2007 (as amended), Government Printer, Pretoria.

South Africa, 2008, Companies Act, No. 61 of 2008 (as amended), Government Printer, Pretoria.

South Africa, 2011, Taxation Laws Amendment Act, No. 24 of 2011, Government Printer, Pretoria.

Standard Bank of South Africa Ltd and Another v Ocean Commodities Inc and Others [1983] 1 All SA 145 (A). (29 September 1982).

Swart, G., 2005, 'Interpreting some core concepts governing the taxation of capital gains', SA Mercantile Law Journal 17(1), 1-18.

Van der Merwe, B.A., 1998, 'Cession of a right to future income - Income tax implications', SA Mercantile Law Journal 10, 354-367.

Van der Merwe, C.G., 2015, Law of South Africa. Theoretical Distinction between real and personal rights, viewed 17 April 2016, from http://www.mylexisnexis.co.za

Van der Walt, A.J. \& Maass, S., 2012, 'The enforceability of tenants' rights (part 1)', South African Law Journal 35(1), 35-52.

Welch v CSARS [2004] 2 All SA 586 (SCA). (21 May 2004). 